\title{
The Danish Quality Database for Cervical Cancer Screening
}

\section{Carsten Rygaard}

Department of Pathology, Copenhagen University Hospital Hvidovre, Hvidovre, Denmark
Correspondence: Carsten Rygaard Department of Pathology, Copenhagen University Hospital Hvidovre, Kettegård Allé 30, 2650 Hvidovre, Denmark Tel + 4523293633

Email rygaardI@hotmail.com
This article was published in the following Dove Press journal:

Clinical Epidemiology

25 October 2016

Number of times this article has been viewed

Aim of database: To monitor and improve the quality of the Danish national cervical cancer screening program, an annual report is published, including nine quality indicators.

Study population: The screening target group consisted of 1.5 million Danish women aged 23-64 years, but in the calculation of quality indicators, the dataset varies according to indicators being Danish women, cervical cancer cases, or cytology samples.

Main variables: The variables include the number of cytology samples per pathology laboratory, participation rate, percentage of unsatisfactory samples, diagnostic sensitivity and specificity, percentage of samples answered within $\leq 10$ days, percentage of atypical squamous cells of undetermined significance samples in women aged $>30$ years with human papillomavirus-triage, coverage, percentage of non-normal samples not followed up according to recommendations, number of incident cervical cancers, incidence of cervical cancer in the past 5 years, and upcoming percentage of incident cervical cancers undergoing audit.

Descriptive data: Annual reports have been published since 2009. Better fulfillment of quality standards has been seen for the size of pathology departments, percentage of unsatisfactory samples, percentage of atypical squamous cells of undetermined significance with human papillomavirus-triage, and a slight decrease in the percentage of non-normal samples not followed up within the recommended time intervals. Stable patterns have been observed for participation rate, coverage, and number of incident cervical cancer cases. With a coverage of $75 \%$, and with presently $16 \%$ of non-normal samples not followed up in a timely manner, there is definitely a scope for improvement in the screening program.

Conclusion: The database has pinpointed the strengths and weaknesses of the national cervical cancer screening program. Measures to enhance participation rate/coverage and to improve follow-up of non-normal cytology samples are warranted.

Keywords: screening, cervical cancer, cytology

\section{Aim of database}

The purpose of the Danish Database for Cervical Cancer Screening is to provide an annual status for the nationwide screening program and to document the screening quality over time by monitoring nine quality indicators. The first annual report covered the activities in 2009 and the latest report covered the activities in $2014 .^{1-6}$

Cervical cancer screening with cytology started in the late 1960s in Denmark, and a decrease in both incidence and mortality has been seen since then, as shown in Figure 1.

In 1986, the Danish National Board of Health issued the first national recommendations. ${ }^{7}$ Women aged $23-59$ years were recommended to be screened every third year. ${ }^{8}$ 


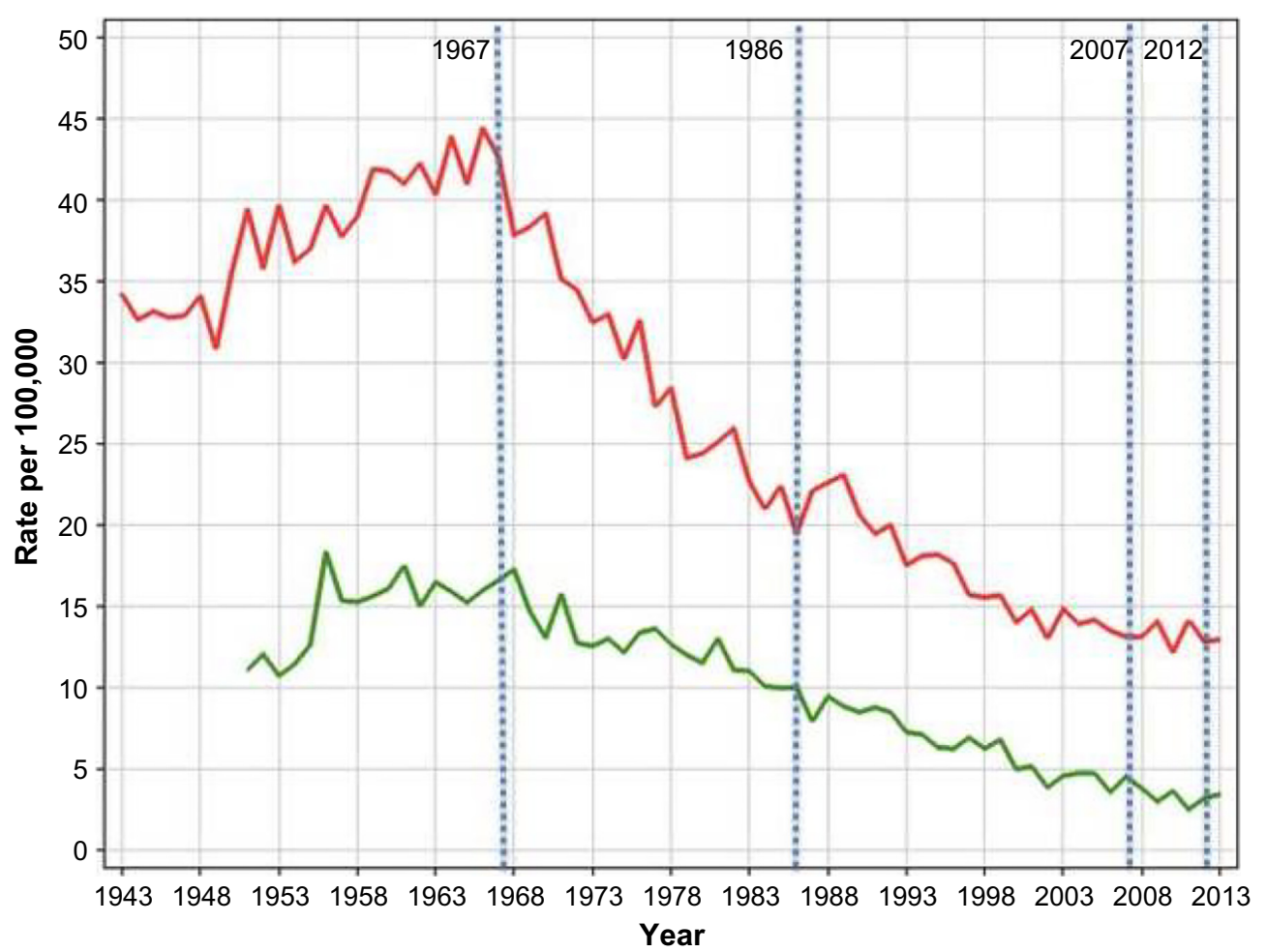

Figure I Danish cervical cancer incidence (red curve) and mortality (green curve) 1943-20I3 (0-85 years of age).

Notes: Age-standardized rate per 100,000 (Nordic standard population). In 1967, start of first organized county-based screening program; 1986, first national guidelines issued; 2007, new national guidelines issued; and 20I2, updated national guidelines issued. Reproduced from Engholm G, Ferlay J, Christensen N, et al. NORDCAN: Cancer Incidence, Mortality, Prevalence and Survival in the Nordic Countries, Version 7.2 (16.12.2015). Association of the Nordic Cancer Registries. Danish Cancer Society. Available from http://www.ancr.nu. Accessed March 16, 1016.13

It took 20 years before these recommendations were fully implemented. In 2007, the recommendations were changed to screening every third year for women aged 23-49 years and every fifth year for women aged 50-64 years. ${ }^{9}$ In 2012 , screening at the age 60 years and over could be replaced by a human papillomavirus (HPV) check out test. ${ }^{10}$

The annual report of the database describes the result of nine quality indicators. The indicators represent a selected and simplified version of the characteristics of a screening program recommended for monitoring in the European Guidelines for Quality Assurance in Cervical Cancer Screening. ${ }^{11}$ All quality indicators are calculated from data available in already established national registers. For each indicator, the steering committee for the database has agreed on a standard that the program should aim to reach as confirmed by the National Board of Health. The indicator data are tabulated on national level, by region, and, in some cases, also by pathology department.

The indicators, the standards, and the achieved outcomes for each year are tabulated in Table 1.

\section{Study population}

The screening target group consisted of 1.5 million Danish women aged 23-64 years. The study population varies from indicator to indicator. Women constitute the study population for indicators 1a, 2, and 7. Cervical cancer cases constitute the study base for indicators $9 \mathrm{a}, 9 \mathrm{~b}$, and 9c. Various parts of the cervical cytology samples constitute the study base for the other indicators. For instance, all cervical samples constitute the study base for indicator 3, while only samples showing atypical squamous cells of undetermined significance (ASCUS) in women older than 30 years constitute the study base for indicator 6 .

Population data are obtained from the Central Population Register, including all persons with a permanent address in Denmark. Cervical cancer cases are obtained from the Danish Cancer Register. Cervical cytology samples are collected from the Patobank covering all activities in Danish pathology laboratories online. All source registers have high validity. The Central Population Register forms the basis for all contacts between the citizens and the authorities; the Danish Cancer Register is nowadays based on direct input from the national health registers; and the Patobank includes data on all specimens analyzed by Danish pathologists. The total annual number of cervical cytology samples was 443,000 in 2009; 390,000 in 2010; 428,000 in $2011 ; 441,000$ in $2012 ; 458,000$ in 2013; and 417,000 in 2014. 
Table I Quality indicators, standards, and achieved outcomes in 2009-2014 for the Database for Cervical Cancer Screening in Denmark

\begin{tabular}{|c|c|c|c|c|c|c|c|c|}
\hline Number & Indicator & Standard & 2009 & 2010 & 2011 & 2012 & 2013 & 2014 \\
\hline I & $\begin{array}{l}\text { Number of cervical } \\
\text { cytology samples per } \\
\text { pathology laboratory }\end{array}$ & $>\mid 5,000 />25,000$ & $\begin{array}{l}14 / 16 \\
\text { laboratories }\end{array}$ & $\begin{array}{l}13 / 16 \\
\text { laboratories }\end{array}$ & $\begin{array}{l}15 / 16 \\
\text { laboratories }\end{array}$ & $\begin{array}{l}15 / 15 \\
\text { laboratories }\end{array}$ & $\begin{array}{l}5 / 10 \\
\text { laboratories }\end{array}$ & $\begin{array}{l}5 / 8 \\
\text { laboratories }\end{array}$ \\
\hline 2 & Participation rate & $>75 \%$ & $66.3 \%$ & $64.9 \%$ & $65.6 \%$ & $64.2 \%$ & $66.6 \%$ & $64.1 \%$ \\
\hline 3 & $\begin{array}{l}\text { Percentage of } \\
\text { unsatisfactory samples }\end{array}$ & $<1.5 \%$ & $3.1 \%$ & $2.6 \%$ & $2.3 \%$ & $1.9 \%$ & $1.8 \%$ & $1.7 \%$ \\
\hline $4 a$ & Diagnostic sensitivity ${ }^{b}$ & $>60 \% />70 \%$ & $63.2 \%$ & $65.0 \%$ & $74.8 \%$ & $66.7 \%$ & 69.3 & $66.9 \%$ \\
\hline $4 b$ & Diagnostic specificity & $>95 \%$ & $97.0 \%$ & $96.8 \%$ & $95.7 \%$ & $95.3 \%$ & 95.2 & $95.3 \%$ \\
\hline 5 & $\begin{array}{l}\text { Percentage of samples } \\
\text { answered in } \leq 10 \text { days }\end{array}$ & $>95 \%$ & $79.4 \%$ & $81.4 \%$ & $86.8 \%$ & $91.1 \%$ & $90.5 \%$ & $87.1 \%$ \\
\hline 6 & $\begin{array}{l}\text { Percentage of ASCUS, } \\
>30 \text { years with HPV- } \\
\text { triage }\end{array}$ & $>95 \%$ & $44.7 \%$ & $59.0 \%$ & $77.2 \%$ & $91.1 \%$ & $92.2 \%$ & $96.4 \%$ \\
\hline 7 & Coverage & $>85 \%$ & $76.0 \%$ & $76.0 \%$ & $75.5 \%$ & $74.9 \%$ & $75.3 \%$ & $75.6 \%$ \\
\hline 8 & $\begin{array}{l}\text { Percentage of } \\
\text { non-normal and } \\
\text { unsatisfactory samples } \\
\text { not followed up as } \\
\text { recommended }\end{array}$ & $<2 \%$ & $20.6 \%$ & $19.9 \%$ & $19.2 \%$ & $20.4 \%$ & $17.8 \%$ & $15.9 \%$ \\
\hline $9 a$ & $\begin{array}{l}\text { Number of incident } \\
\text { cervical cancers }\end{array}$ & $<350$ & 396 & 342 & 399 & 361 & 370 & NR \\
\hline $9 b$ & $\begin{array}{l}\text { Incidence of cervical } \\
\text { cancer the last } \\
5 \text { years }^{c}\end{array}$ & $<13.9$ & 14.3 & 12.5 & 14.5 & 13.1 & 13.3 & NR \\
\hline $9 c$ & $\begin{array}{l}\text { Percentage of cervical } \\
\text { cancer with audit } \\
\text { from } 2012\end{array}$ & $>95 \%$ & NR & NR & NR & $68.9 \%$ & $71.4 \%$ & NR \\
\hline
\end{tabular}

Notes: aln 2012, the number of annual cytology samples per screening laboratory was changed from I5,000 to 25,000. bln 201।, the diagnostic sensitivity was changed from $60 \%$ to $70 \%$. 'Age-standardized incidence per 100,000 (standard: Danish women 2005).

Abbreviations: ASCUS, atypical squamous cells of undetermined significance; HPV-triage, human papilloma virus triage; NR, no registration.

\section{Main variables}

Indicator 1 (number of cervical cytology samples per pathology laboratory) has the aim to monitor the centralization of cytology service in Denmark (Table 1). The Danish national cervical cancer screening program is organized in an integrated fashion, where only women not already registered with a cytology sample in the Patobank within the recommended screening interval are invited. Therefore, indicator 2 (participation rate) covers only response to invitation, which means that it is calculated as the number of women who participate after having received invitation divided by the number of all invited women. Indicator 3 (percentage of unsatisfactory samples) shows that this percentage has dropped from a previous level of $3.1 \%$ to a present level of $1.7 \%{ }^{1,6}$ This percentage has decreased with the introduction of liquid-based cytology, which is used throughout Denmark from 2014.

Indicator 4 (diagnostic quality) represents an attempt to calculate sensitivity and specificity based on the already available data in the Patobank. This means that several compromises had to be made in the calculation. Cytology samples from a given year are divided into normal and abnormal tests and compared with the outcome of follow-up samples within the next 3.5 years. Normal cytology not followed by any high-grade cytology/histology or not followed by any test is defined as "true negative". Normal cytology followed by any high-grade cytology/histology is defined as "false negative". Abnormal cytology followed by any high-grade cytology/histology is defined as "true positive". Abnormal cytology not followed by any high-grade cytology/histology or not followed by any test is defined as "false positive". These indicators are not comparable with sensitivity and specificity data from other sources, eg, from the scientific literature. They are included nevertheless to facilitate the detection of differences in performance across Danish pathology laboratories and the development over time.

The purpose of indicator 5 (percentage of samples answered in 10 days) is to monitor workflow in the laboratories. Indicator 6 (percentage of ASCUS, women $>30$ years with HPV-triage) is recommended by the Danish National Board of Health in 2007, although at that time still optional as not all pathology laboratories were able to undertake HPV testing in 2007. ${ }^{9}$ It became mandatory in 2012, and indicator 
6 monitors this implementation. ${ }^{10}$ Indicator 7 (coverage) measures the target population's coverage by screening within the recommended time interval, which means that it is calculated as the number of women screened in the recommended time interval divided by the total number of women.

Indicator 8 monitors the follow-up of non-normal and unsatisfactory samples. The Danish National Board of Health has published a flow diagram to be followed for non-normal samples. Unsatisfactory samples for instance have to be followed by a new cytology sample within 3 months. Highgrade lesions (high-grade squamous intraepithelial lesions [HSILs], adenocarcinoma in situ, atypical squamous cells cannot exclude HSIL, and atypical glandular cells) have to be followed with colposcopy and biopsies within 3 months. Indicator 8 (percentage of non-normal and unsatisfactory samples not followed up as recommended) summarized the completion of follow-up across all non-normal samples. The percentage has dropped from a previous level of $20.6 \%$ to a present level of $15.9 \%{ }^{1,6}$

Indicator 9 gives the number of incident cervical cancer cases reported to the Danish Cancer Register. As the cancer register is normally $1-2$ years behind the annual report, numbers from previous years are included in the annual reports.

The national guidelines from 2012 recommend audit of all incident cervical cancer cases. Audit should include rereading of all previously normal cytology and histology samples 3.5 years back for women aged 23-49 years and 5.5 years back for women aged 50-64 years. Audit has been difficult to implement, among other things, because some discrepancies have been found between the Danish Cancer Register and the Patobank. Indicator 9c is expected to be fully reported from 2015 onward.

\section{Follow-up}

The follow-up data are needed for many of the indicators. This means, for instance, that the data in the 2014 annual report for indicator 8 were taken from the period October 1, 2012, to September 30, 2013, which allows for observation of followup activities within the recommended time intervals.

Follow-up is possible because all data are registered online in the Patobank by personal identification number. It is thus possible to link samples from a given woman into a screening history.

\section{Examples of research}

The database has given rise to important observations. First, despite the inclusion of all opportunistically taken samples in the Patobank, and the use of two reminders for women not responding to an invitation, Denmark still has - similar to other countries - a screening coverage of only $~ 75 \%{ }^{6}{ }^{6}$ As in other countries, coverage is the main indicator of program success. Among incident cases of cervical cancer in 2003-2007, 45\% had not been screened at any time with the last two screening rounds. ${ }^{12}$ The database shows that use of reminders is an efficient tool in increasing participation and thus coverage. Based on the reported data from 2014, it can be calculated that $40 \%$ of invited women responded to the invitation, $16 \%$ responded to the first reminder, and $8 \%$ responded to the second reminder. ${ }^{6}$ Self-sampling of nonresponders is now being pilot tested in the Capital Region, in order to increase the coverage further by expected $5 \%-7 \%$ points.

Second, a screening program will fail if non-normal samples are not followed up adequately. The standard was therefore set to $<2 \%$. But the reality turned out differently. In 2009-2012, almost 20\% of non-normal samples had not been followed up within the recommended time intervals. ${ }^{1-4}$ Timely follow-up of non-normal samples is a challenge for the screening program, one of the problems being that the responsibility rests with the sample taker, which is normally the general practitioner. Various measures have been implemented in order to ensure timely follow-up, and since 2012 an automatic mail reminder is sent directly to the sample taker, if there is no follow-up according to the recommendation.

Nevertheless, in 2013 still 15.9\% of non-normal samples were not followed up as recommended. When the time window for follow-up was extended to 450 days, $6.4 \%$ of samples were not followed up. ${ }^{6}$ When only severe cellular abnormalities (HSIL, adenocarcinoma in situ, atypical squamous cells cannot exclude HSIL, and atypical glandular cell) were considered, $4.7 \%$ were not followed up as recommended within 90 days, and $2.8 \%$ of these samples were not followed up within 180 days.

Women aged $>30$ years with ASCUS and negative HPVtriage are recommended to return to the screening program. The database shows that HPV-triage for these women is now with $96.4 \%$ almost completely implemented. ${ }^{6}$ This has saved many women from the repeated cytology testing after 6 months and again after 12 months, which was recommended before the use of HPV-triage.

\section{Administrative issues and funding}

The Danish Quality Database for Cervical Cancer Screening is managed by a national steering committee consisting of pathologists from the local steering group in each of the five Danish Regions and representatives from the national societies 
for pathology, cytology, gynecology, and the Patobank. The steering committee provides an annual web-based report and is responsible for optimizing and managing the database.

The database receives support from the Registry Support Centre of Epidemiology and Biostatistics (North) and Registry Support Centre of Clinical Quality and Health Informatics (West).

The database is available for research according to rules in the Danish legislation for register-based research.

The Danish Quality Database for Cervical Screening is funded by the Danish Regions (Accessed January 15, 2016).

\section{Conclusion}

The database has been instrumental in indicating the weak spots in the Danish national cervical cancer screening program: the relatively low coverage and the lack of adequate follow-up of non-normal samples. For both problems, various measures have now been implemented in order to improve the situation. The ultimate check on these measures is the number of incident cervical cancer cases, which although close to the target of $<350$ cases per year has remained fairly stable over the past 5 years with an incidence rate of 13.3 per 100,000 (standard: Danish women 2005). ${ }^{6}$

\section{Acknowledgments}

Members of the steering committee for the database in August 2015 are as follows: Jette Ahrensberg, Berit Andersen, Jette Christensen, Dorthe Ejersbo, Anne Gammelgaard, Kirsten Jochumsen, Ellen M Mikkelsen, Mari-Ann Munch, Karsten Nielsen, Carsten Rygaard (chairperson 2007-2015), Hans Svanholm, and Marianne Waldstrøm. Elsebeth Lynge acts as external consultant for the committee. Participants from Registry Support Centre of Epidemiology and Biostatistics (North) are Lea Grey Haller and Frank Mehnert. This paper was funded by the Program for Clinical Research Infrastructure (PROGRIN) established by the Lundbeck Foundation and the Novo Nordisk Foundation and administered by the Danish Regions.

\section{Disclosure}

The author reports no conflicts of interest in this work.

\section{References}

1. Styregruppen for DKLS [webpage on the Internet]. DKLS Annual Report 2009, Dansk Kvalitetsdatabase for Livmoderhalskræftscreening; 2010 [in Danish]. Available from: http://danskpatologi.dk/doc/ DSPAC_pdf $/ \%$ C3\%85rsrapport\%20DKLS\%202009_final.pdf. Accessed January 14, 2016.
2. Styregruppen for DKLS [webpage on the Internet]. DKLS Annual Report 2010. Dansk Kvalitetsdatabase for Livmoderhalskræftscreening; 2011 [in Danish]. Available from: https://www.sundhed.dk/content cms/80/1880_aarsrapport-2010-livmoderhalskraeftscreening.pdf. Accessed January 14, 2016.

3. Styregruppen for DKLS [webpage on the Internet]. DKLS Annual Report 2011. Dansk Kvalitetsdatabase for Livmoderhalskræftscreening; 2012 [in Danish]. Available from: https://www.sundhed.dk/content cms/82/4682_dkls-\%C3\%A5rsrapport-2011-dfs-270612.pdf. Accessed January 14, 2016.

4. Kompetencecenter for Epidemiologi og Biostatistik Nord (KCEB Nord) [webpage on the Internet]. DKLS Annual Report 2012. Dansk Kvalitetsdatabase for Livmoderhalskræftscreening; 2013 [in Danish]. Available from: https://www.sundhed.dk/content/cms/82/4682_dkls\%E5rsrapport-2012.pdf. Accessed January 14, 2016.

5. Kompetencecenter for Epidemiologi og Biostatistik Nord (KCEB Nord) [webpage on the Internet]. DKLS Annual Report 2013. Dansk Kvalitetsdatabase for Livmoderhalskræftscreening; 2014 [in Danish]. Available from: https://www.sundhed.dk/content/cms/82/4682_dkls\%C3\%A5rsrapport-august_vers3-8_final.pdf. Accessed January 14, 2016.

6. Kompetencecenter for Epidemiologi og Biostatistik Nord (KCEB Nord) [webpage on the Internet]. DKLS Annual Report 2014. Dansk Kvalitetsdatabase for Livmoderhalskræftscreening; 2015 [in Danish]. Available from: https://www.sundhed.dk/sundhedsfaglig/kvalitet/ kliniske-kvalitetsdatabaser/screening/livmoderhalskraeftscreening/. Accessed August 14, 2015.

7. Sundhedsstyrelsen. Preventive Examinations for Cervical Cancer Committee on Cervical Cancer Examinations. Copenhagen: National Board of Health (Sundhedsstyrelsen); 1986. [in Danish].

8. Lynge E, Arffmann E, Behnfeld L, et al. Forebyggende undersøgelser for livmoderhalskræft i Danmark. Status i 1995. Planer for 1996 [Preventive examinations for cervix cancer in Denmark. Status in 1995. Plans for 1996]. Ugeskr Laeger. 1996;158(35):4916-4919. [in Danish].

9. Sundhedsstyrelsen [webpage on the Internet]. Screening for Cervical Cancer-Recommendations. Copenhagen: National Board of Health (Sundhedsstyrelsen); 2007. [in Danish]. Available from: https://sundhedsstyrelsen.dk/da/sundhed/folkesundhed/screeningsprogrammer/ livmoderhalskraeftscreening\#. Accessed August 14, 2015.

10. Sundhedsstyrelsen [webpage on the Internet]. Screening for Cervical Cancer-Recommendations. Copenhagen: National Board of Health (Sundhedsstyrelsen); 2012. [in Danish - with summary in English]. Available from: https://sundhedsstyrelsen.dk/da/sundhed/folkesundhed/ screeningsprogrammer/livmoderhalskraeftscreening\#. Accessed August 14, 2015.

11. European Commission, Directorate-General for Health and Consumers. European Guidelines for Quality Assurance in Cervical Cancer Screening. Luxembourg: Office for Official Publications of the European Communities; 2008

12. Dugué PA, Lynge E, Bjerregaard B, Rebolj M. Non-participation in screening: the case of cervical cancer in Denmark. Prev Med. 2012;54(3-4):266-269.

13. Engholm G, Ferlay J, Christensen N, et al. NORDCAN: Cancer Incidence, Mortality, Prevalence and Survival in the Nordic Countries, Version 7.2 December 16, 2015. Association of the Nordic Cancer Registries. Danish Cancer Society. Available from http://www.ancr.nu. Accessed March 16, 1016. 


\section{Publish your work in this journal}

Clinical Epidemiology is an international, peer-reviewed, open access, online journal focusing on disease and drug epidemiology, identification of risk factors and screening procedures to develop optimal preventative initiatives and programs. Specific topics include: diagnosis, prognosis, treatment, screening, prevention, risk factor modification,

Submit your manuscript here: http://www.dovepress.com/clinical-epidemiology-journal systematic reviews, risk \& safety of medical interventions, epidemiology \& biostatistical methods, and evaluation of guidelines, translational medicine, health policies \& economic evaluations. The manuscript management system is completely online and includes a very quick and fair peer-review system, which is all easy to use. 